\title{
STUDIES ON CARBONIFEROUS INSECTS FROM COMMENTRY, FRANCE: PART V. THE GENUS DIAPHANOPTERA AND THE ORDER DIAPHANOPTERODEA
}

\author{
By F. M. Carpenter \\ Harvard University
}

This is the fifth in a series of studies based on the Carboniferous insects from the Commentry Basin, France. ${ }^{1}$ It consists of an analysis of the genus Diaphanoptera Brongniart and a discussion of the Order Diaphanopterodea, which was erected by Handlirsch in 1919 to receive the genus. In more recent years, there have been described other Carboniferous and Permian genera which, although previously placed in the Order Megasecoptera, now appear to belong to the Diaphanopterodea. This group of insects, apparently having a combination of palaeopterous and neopterous characteristics, presents one of the most intriguing and puzzling problems in the geological history of the insects. Our unsatisfactory knowledge of the Commentry fossils has added to the difficulties.

\section{Survey of Commentry Species}

Diaphanoptera was established by Brongniart in 1893 to include two species, D. munieri Brongniart and $D$. vetusta Brongniart, both from the Commentry shales. The specimen of one (munieri) consists of a complete wing, and of the other (vetusta), of the apical half of a wing. The genus was placed by Brongniart in the group of fossils he termed the "Megasecopterida", including Aspidothorax, Sphecoptera, Psilothorax, etc. In the same publication, Brongniart described a fossil, consisting of a whole but poorly preserved specimen with very long cerci, as Anthracothremma scudderi, placing it in another "family", the "Protephemerides", along with Triplosoba and Homaloneura. In his 1906 treatise, Handlirsch followed Brongniart's treatment of Diaphanoptera, but he removed scudderi from Anthracothremma, placing it in a new genus, Pseudanthracothremma, which he allocated to an incertae sedis category, the ordinal position being uncertain.

${ }^{1}$ This research has been aided by a grant (NSF-G14099) from the National Science Foundation and by a previous grant from the Penrose Fund of the American Philosophical Society (1938). I am indebted to the authorities of the Laboratoire de Paléontologie of the Muséum National d'Histoire Naturelle in Paris for placing at my disposal the unique collections of Commentry insects in the Muséum, in 1938, 1961, and 1963; and to the authorities of the British Museum (Natural History) for allowing me to examine the Commentry fossils in that institution. The previous paper in this series was published in Psyche, vol. 70. pp. 120-128, 1963. 
Shortly after this, Meunier described (1908) as Diaphanoptera superba, a specimen which showed all four wings held back over the abdomen; the venation was very clear but virtually no body parts were preserved. Meunier recognized that the affinites of this fossil were with Brongniart's species of Diaphanoptera, but he made no comments in his paper on the wings being flexed over the abdomen. Lameere, who examined the Brongniart and Meunier specimens in Paris, noted (I9I7) that Pseudanthracothremma scudderi is very close to, if not the same species as, Diaphanoptera superba, reaching this conclusion because of the general similarity of size and form of the two fossils, and the nature of the fragmentary venation known in scudderi; and that in both specimens of superba and scudderi the wings rest obliquely along the abdomen (i.e., neopterous-like), not perpendicular to the body (i.e., palaeopterous-like), as in all other Megasecoptera then known. Nevertheless, he continued to place Diaphanoptera in the Megasecoptera. Handlirsch, in his superficial revision of Palaeozoic insects (1919), established a new genus, Diaphanopterites, and a new family, Diaphanopteritidae, for Meunier's superba. Unfortunately, he did not see the fossil itself and his interpretation of it was based entirely on Meunier's incorrect drawing and on a small, published photograph. The flexed position of the wings led Handlirsch to remove these diaphanopterids from the Megasecoptera and to establish a new order, Diaphanopteroidea, for their reception.

As a result of my examination of the fossils mentioned above, I propose the following classification of the Diaphanopteridae from the Commentry shales.

Order Diaphanopterodea Handlirsch

Family Diaphanopteridae Handlirsch (synonym: Diaphanopteritidae Handlirsch)

Genus Diaphanoptera Brongniart (synonyms: Diaphanopterites Handlirsch; Pseudanthracothremma Handlirsch) munieri Brongniart (type-species)

vetusta Brongniart

scudderi (Brongniart)

superba Meunier

The family Diaphanopteridae is also represented in Upper Carboniferous strata of the Soviet Union; other families apparently belonging to the Order Diaphanopterodea have been found in Upper Carboniferous and Permian beds of the Soviet Union and the United States. A discussion of the characteristics and relationships of the Diaphanopterodea will follow the detailed account of the Commentry fossils. 
Family Diaphanopteridae Handlirsch

Diaphanopteridae Handlirsch, 1906, Foss. Ins. :313

[= Diaphanopteritidae Handlirsch, 1919; Denks., Akad. Wiss. Wien, 96:65]

Fore and hind wings similar; Sc terminating on $\mathrm{R}_{\mathrm{I}}$ slightly beyond mid-wing; MA diverging away from MP immediately after its origin and just touching or very nearly touching Rs before continuing as an independent, convex vein; $\mathrm{CuA}$ coalesced with the base of M. Several large, thickened, circular spots on membrane of both wings. Body

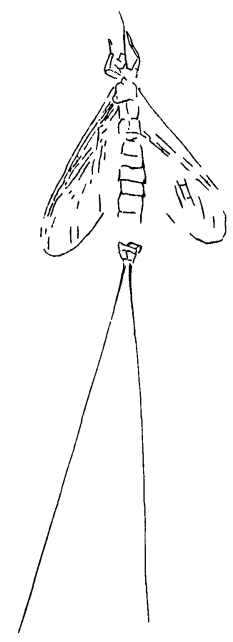

Text figure 1. Diaphanoptera scudderi (Brongniart), after Brongniart, 1893.

structure little known; thorax and abdomen combined about as long as wings; abdomen slender; cerci very long, about twice as long as wings.

There seems to me no basis for accepting Handlirsch's family Diaphanopteritidae, which was erected for Diaphanoptera superba Meunier. The diagnosis given by Handlirsch for the family is very vague and his interpretation of the venation of superba, based entirely on Meunier's published photograph, is inaccurate.

In addition to the Genus Diaphanoptera, which is now known only from the Commentry shales, the family Diaphanopteridae is represented in the Upper Carboniferous strata of the Kuznetsk Basin (Asian RSFSR), Soviet Union, by Philiasptilon maculosum Zalessky ( I931). Although only the distal half of a wing of this insect is known, its affinites with Diaphanoptera are obvious; two circular spots on the wing membrane correspond approximately in position to spots in Diaphanoptera. 
The nature of the circular, cuticular thickenings on the wings of Diaphanoptera is by no means clear. Forbes (1943) identifies them as nygmata, ${ }^{2}$ and, incidentally, considers Diaphanoptera to be a true neuropteron, closely related to the living genus Corydalis. However, cuticular thickenings occur in certain families of Palaeozoic insects which can hardly be regarded as endopterygotes, e.g., the Mischopteridae of the Megasecoptera, which are clearly Palaeoptera, and the Cacurgidae of the Protorthoptera, to cite only two examples. The spots in all these Palaeozoic forms are much larger than the nygmata of the endopterygote insects and there is certainly no reason to regard them as homologous structures. Forbes' figure of Diaphanoptera (1943) represents the spots as very small, like nygmata, although they are actually large (see plate 28 ).

\section{Genus Diaphanoptera Brongniart}

Diaphanoptera Brongniart, 1893, Recherches Hist. Ins. Foss. :308; Handlirsch, 1906, Foss. Ins.: 313 ; Lameere, 1917, Mus. Nat. Hist. Natur., Bull. 23 :148. Pseudanthracothremma Handlirsch, 1906, Foss. Ins.:324; Lameere, 1917, Mus. Nat. Hist. Natur., Bull. $23: 148$.

Diaphanopterites Handlirsch, 1919, Denkschr. Akad. Wiss. $96: 66$.

Hind wing very slightly broader distally than the fore wing and apex slightly more rounded. Rs with from 5 to 7 branches; $\mathrm{R}_{4}+5$ parallel with MA; MA unbranched; MP with from 4 to 5 branches; $\mathrm{CuA}$ unbranched; CuP branched.

Type-species: Diaphanoptera munieri Brongniart [Designation by Handlirsch, I922].

The generic characteristics given above are somewhat arbitrary, since only one other genus, Philasptilon, is known in the family. The latter, represented by an incomplete wing, differs from Diaphanoptera in having $\mathrm{R}_{4}+5$ and MA converging distally; at the point of its origin $\mathrm{R}_{4}+5$ is much more remote from MA than it is further distally. The rest of the known venation of Philasptilon is very close to that of Diaphanoptera. I am following Lameere in considering Pseudanthracothremma a synonym of Diaphanoptera; it has flexed wings and very long cerci, and the few veins that can be seen in the fossil are like those of Diaphanoptera. Diaphanopterites is even more clearly a synonym. The distinguishing characteristics attributed by

\footnotetext{
${ }^{2}$ The term nygmata is a modification (Forbes, 1924) of "nigmas" proposed by Navas in 1917 for small cuticular spots which occur on the wings of certain Trichoptera, Neuroptera and related Endopterygota and which grade into similar spots in other insects. Very little is known of their structure and nothing of their function. Martynov (1925) has published the only account of their histology, Martynova (1949) has investigated their presence and distribution in Permian Mecoptera. and Jolivet (1955) has studied the external structure of a variety of types. They have been regarded as probably either glandular or sensory structures.
} 


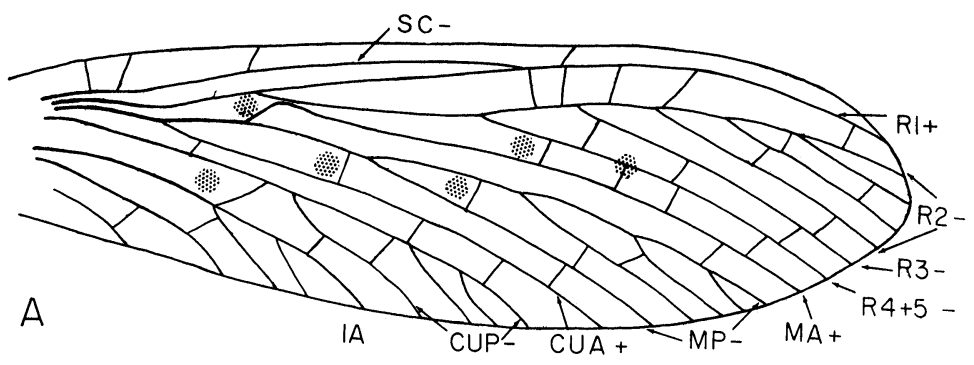

B
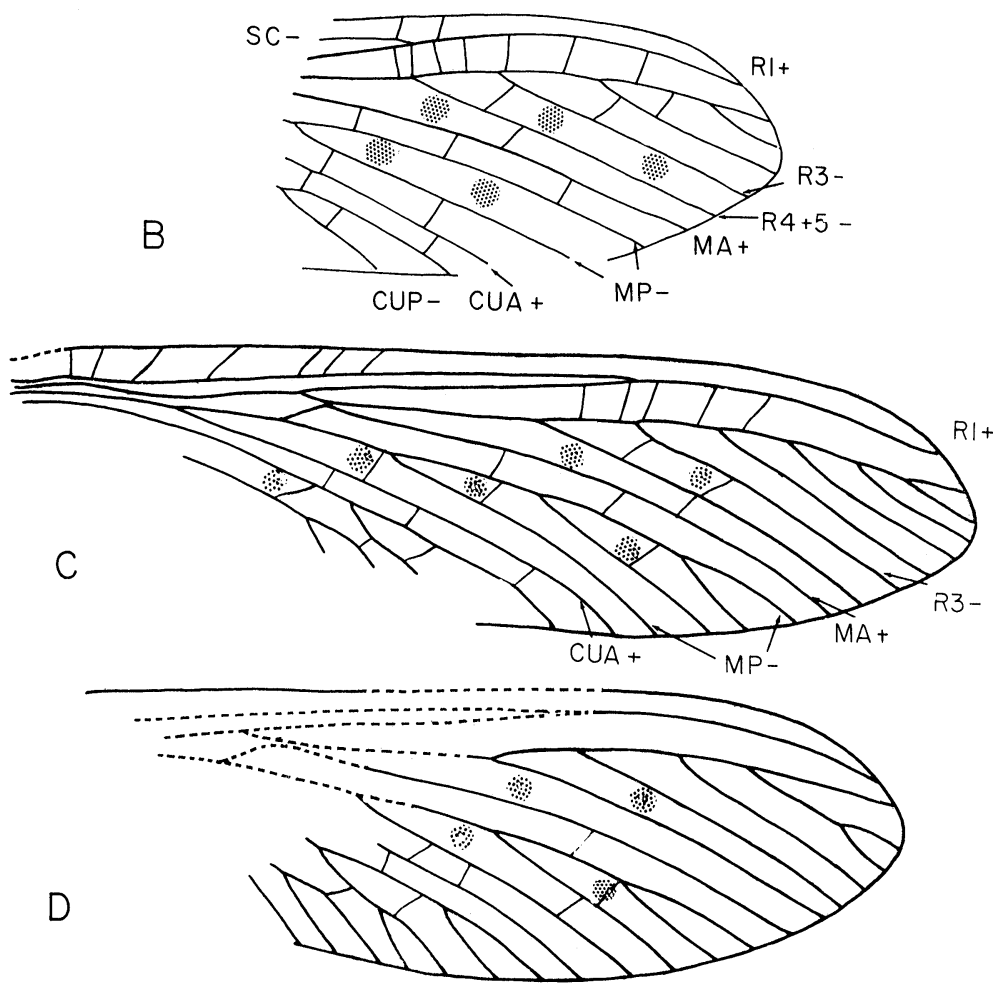

Carpenter - Diaphanoptera 
Handlirsch to the genus do not exist; Sc, for example, was described as extending to the wing apex, but it actually terminates just beyond mid-wing, as in Diaphanoptera.

\section{Diaphanoptera munieri Brongniart}

Plate 28, A

Diaphanoptera munieri Brongniart, 1893, Recherches Hist. Ins. Foss.:309, pl. 17, fig. 10; Handlirsch, 1906, Foss. Ins.:313, pl. 32, fig. 8; Lameere, 1917, Mus. Nat. Hist. Natur., Bull. $23: 149$.

This species was based on a single, well-preserved wing, $38 \mathrm{~mm}$. long and I I $\mathrm{mm}$. wide; on the basis of the shape, I assume it is a hind wing. Its venation is shown in plate 32, fig. A, which is drawn directly from the type specimen in the Laboratoire de Paléontologie. All main veins are clearly preserved and their convexities or concavities distinct. Brongniart's figure of the wing, although very small, correctly represents the venation except in two areas: (I) The proximal parts of Sc and $\mathrm{R}_{\mathrm{I}}$ are distinctly bent, as in other primitive Diaphanopterodea; and the stems of $R$ and $M$ are independent, not in contact, as suggested in Brongniart's drawing. (2) MA, distinctly convex, arises from $M$ at about the level of origin of Rs and then diverges abruptly towards Rs. These two veins do not, however, quite coalesce, as is shown in Brongniart's figure; there is, in fact, a narrow space between them, even at the point of closest association. Handlirsch's figure of $C$. munieri (1906), crudely copied from Brongniart's work, shows the basal piece of MA as very weak and nearly transverse. This illustration, which is definitely incorrect, has been reproduced in various publications on wing venation and fossil insects (e.g., Comstock, 1918; Rohdendorf, 1962). Forbes' figure (1943), although based on Brongniart's, is somewhat altered, depicting a broader, more oval wing, and representing the base of MA by a broken line. Actually, the basal origin of MA and its divergence to and away from Rs are clearly preserved in the fossil.

Like the other diaphanopterids, munieri shows several large spots on the wing. Brongniart indicated six of these in his figure and I find this number in the fossil; but I believe he included one which is actu-

\section{Explanation of Plate 28}

DiAPHANOPTERA

A. Fore wing of D. munieri Brongniart (type).

B. Distal part of fore wing of $D$. vetusta Brongniart (type).

C. Fore wing of $D$. superba Meunier (type).

$D$. Hind wing of $D$. superba Brongniart (type).

All drawings original, based on specimens in Laboratoire de Paleontologie, Paris. Sc, subcosta; $R 1$ radius; $R 2, R 3, R 4+5$, branches of radial sector; $M A$, anterior media; $\mathrm{MP}$, posterior media; $\mathrm{CuA}$ anterior cubitus; $\mathrm{CuP}$, posterior cubitus; + , convex veins; - , concave veins. 
ally not present and that he omitted one. The one which he omitted is located between $\mathrm{CuP}$ and I A the one which he shows most distally is, I believe, only an irregularity in the rock, not part of the wing; its appearance is very different from that of the others.

\section{Diaphanoptera vetusta Brongniart Plate 28, B}

Diaphanoptera vetusta Brongniart, 1893, Recherches Hist. Ins. Fiss.:311; pl. 17, fig. 9; Lameere, 1917, Mus. Nat. Hist. Natur., Bull. $23: 147$.

This species was based on a well-preserved specimen, consisting of about the distal third of the wing, $20 \mathrm{~mm}$. long and $10 \mathrm{~mm}$. wide; the shape of the apex suggests a fore wing. Brongniart's drawing is essentially correct, except that the first branch of Rs has an additional fork, which he did not show. The species is probably distinct from munieri on the basis of the reduced (i.e., forked) MP and the less extensive Rs. Of particular interest are the wing spots, some of which differ in location from those of munieri: there are two between $\mathrm{R}_{3}$ and $\mathrm{R}_{4}+5$ and two between MPI and MP2, instead of only one, as in munieri.

\section{Diaphanoptera scudderi (Brongniart)}

\section{Text figure I}

Anthracothremma scudderi Brongniart, 1893, Hist. Ins. Foss.:329; pl. 18, fig. 10.

Pseudanthracothrem ma scudderi Handlirsch, 1906, Foss. Ins.:324.

Diaphanoptera scudderi Lameere, 1917, Mus. Nat. Hist. Natur., Bull. 23 :149.

This species was based on a poorly preserved fossil, representing a whole insect, the wings $(33 \mathrm{~mm}$. long and I $\mathrm{mm}$. wide) resting obliquely along the abdomen and the cerci extending fully twice the length of the body; suggestions of the thorax and two legs are present but are too vague to have morphological meaning. Brongniart's figure is essentially correct. The wing venation is so obscure that no satisfactory description or drawing of it can be made; however, the pattern, so far as it can be seen, is consistent with that of Diaphanoptera. There are faint indications of the wing spots but their disposition is not clear because of the confused venation.

Brongniart, not recognizing the affinities of this fossil with his Diaphanoptera, placed it in Scudder's genus Anthracothremma, which had been established for an "orthopteroid" species from North America. Brongniart assigned Anthracothremma to the "protephemerides", along with Triplosoba. Handlirsch ( 1906) correctly removed scudderi from Anthracothremma, erecting a new genus, Pseudanthracothremma, which he placed ( 1922 ) in Insecta incertae sedis. In the meantime, however, Lameere (1917), during his examination of the Commentry fossils in Paris, had noted the similarity of the specimen 
of scudderi to the type of Meunier's Diaphanoptera superba and even considered it a possible synonym of superba.

The significance of the specimen is that it shows that Diaphanoptera had very long cerci, similar to those subsequently found in other Diaphanopterodea.

\section{Diaphanoptera superba Meunier}

Plate 28, C, D; Plate 29

Diaphanoptera superba Meunier, 1908, Ann. Soc. Scient. Brux., $32: 155 ; 1908$, Mus. Nat. Hist. Natur., Bull. $14: 173$; 1909, Ann. Paleont. 4:141, pl. 2, fig. 4; Lameere, 1917, Mus. Nat. Hist. Natur., Bull. 23 :148.

Diaphanopterites superbus Handlirsch, 1919, Denkschr. Akad. Wiss. 96:66.

The type and only known specimen of this species consists of a whole specimen, shown in ventral view (counterpart not preserved), the wings resting obliquely along the abdomen. The structure of the thorax and abdomen is only vaguely indicated; cerci, as well as other appendages and the head, are not preserved. The wings, however, are very clearly shown and except for the parts covered by the abdomen the venation can readily be worked out. Convexities and concavities are distinct. No satisfactory drawing of this fossil has been published. Meunier's bears little resemblance to the actual fossil, having subpetiolate wings and complete absence of $\mathrm{Sc}$ in the hind wing. Handlirsch's figure, based entirely on Meunier's very small published photograph, is misleading in almost all respects, showing anal lobes on the hind wings. This specimen is the most important of all those known in Diaphanoptera. The drawing in the accompanying figure includes only what can clearly be seen of the venation in the fossil, with some restored parts indicated by dotted lines. The specimen shows the basal curvature of $\mathrm{Sc}$ and $\mathrm{R}_{\mathrm{I}}$, as well as the characteristically radiating arrangement of the costal cross veins. In most respects the venation is close to that of munieri, although $\mathrm{CuP}$ is less branched in the latter. The wing spots are somewhat different; superba lacks the one at the origin of Rs but has an extra one in the area between $\mathrm{MP}_{3}$ and $\mathrm{R}_{4}+5$; so far as they are preserved, the spots in the hind wing of superba are placed like those of the fore wing. There are no cerci visible in the specimen of superba. At the end of the abdomen there is a short projection or extension, which might be part of an ovipositor.

\section{The Order Diaphanopterodea ${ }^{3}$}

Handlirsch erected this order in 1919 for the family Diaphanopteridae. He gave two reasons for the ordinal separation of this family

\footnotetext{
${ }^{3} \mathrm{Handlirsch}$ 's spelling of the ordinal name, Diaphanopteroidea, is unsatisfactory since the suffix "oidea" is ordinarily used for subordinal names. I have accordingly followed Rohdendorf's altered version (1962).
} 
from the Megasecoptera, to which he had previously assigned it: first, the resting position of the wings (along the abdomen, as shown in the type of superba); and second, the presence of an anal lobe on the hind wing. The latter characteristic does not actually exist in the fossil - Handlirsch simply incorrectly interpreted the photograph of superba published by Meunier. But as to the resting position of the wings, there can be no question. ${ }^{4}$

The Order Diaphanopterodea has not generally been accepted by students of fossil insects, the Diaphanopteridae being placed in the Order Megasecoptera, as previously. In recent years, however, several families apparently related to the Diaphanopteridae have been described from Upper Carboniferous strata of the Soviet Union and North America. These fossils, which have in the past been included in the Megasecoptera along with Diaphanoptera, furnish evidence which supports the validity of the Order Diaphanopterodea. In I96I, during my visit to the Institute of Paleozoology at Moscow, I discussed the question of the Diaphanopterodea with the staff of the Institute (Drs. Rohdendorf, Martynova, Sharov, and their associates) and learned that they also were convinced of the validity of the Order Diaphanopterodea. In their subsequent publication, Osnovy (1962), the order is treated as consisting of twelve families. However, since this work includes no discussion of the reasons for recognizing the order or of the general question of its relationships, I am presenting here my own views on the order and an account of the puzzling morphological features of the insects in this group.

The following are the families which now appear to belong to the Diaphanopterodea, in addition to Diaphanopteridae:

I. Prochoropteridae Handlirsch, I9I I (emend. Carpenter, 1940) [Upper Carboniferous, North America]. The genus Prochoroptera Handlirsch is based on a single specimen showing the wings held over the abdomen, as in Diaphanoptera, and indicating vague outlines of the abdomen, which bears what appears to be the basal part of a large ovipositor. It was placed by him in the Megasecoptera in I9I I and again in 1919, although the Order Diaphanopterodea was therein erected for Diaphanoptera on the wing position. Haupt (I94r) established the Order Palaeohymenoptera for Prochoroptera but gave no reasons for connecting the genus with the hymenopterous line of insects; like Handlirsch, he did not associate it with the Diaphanop-

\footnotetext{
${ }^{4} \mathrm{Handlirsch}$ (1919) treated this difference in wing position as ordinal only and not as indicating a major development in the evolution of insects. Martynov (1923) and Crampton (1924) were the first to propose independently the concept of the Palaeoptera and Neoptera (Archipterygota and Neopterygota of Crampton).
} 
teridae. A second prochopterid, Euchoroptera Carpenter from Kansas (Stanton formation), was based on a single, whole specimen, the wings resting along the abdomen; in addition there is clear preservation of a rostrum (details not discernible), a large ovipositor and a pair of very long cerci, about twice the length of the insect's body.

2. Asthenohymenidae Tillyard, I924 (emend. Carpenter, I939) [Lower Permian, Kansas]. This was placed by Tillyard, along with the family Protohymenidae, in a new order, the Protohymenoptera, but was later transferred to the Megasecoptera. Additional material from Kansas (Carpenter, I93 I, I939) belonging to both these families showed that although the Protohymenidae were palaeopterous (their wings always being preserved in the outspread position), the asthenohymenids clearly rested with their wings over the abdomen, in an apparently neopterous position. These additional fossils also showed that the asthenomymenids possessed a well developed ovipositor, a pair of very long cerci, and a prominent beak.

3. Martynoviidae Tillyard, I932 (emend. Carpenter, I943) [Lower Permian, Kansas, Okla.]. Tillyard placed this family in the sialoid Neuroptera, although he noted some features suggesting the Protohymenoptera. Additional material, including the hind wings, showed that the martynoviids were close to the Prochoropteridae and Asthenohymenidae (Carpenter, I947). The body structure and the resting position of the wings are unknown.

4. Elmoidae Tillyard, I937 (emend. Carpenter, I943, I947) [Lower Permian, Kansas, Okla.]. This was assigned by Tillyard to the Neuroptera, although he recognized a possible relationship to the Protohymenidae and Asthenomymenidae. Additional genera, belonging to this family (Carpenter, 1947) from Lower Permian beds of Oklahoma, made the relationship to the Asthenohymenidae and Martynoviidae more clear. The body structure of the Elmoidae is unknown, but a whole specimen shows that the wings were held over the abdomen at rest.

Using as a basis the features of the five families considered above, we are able to assign the following characteristics to the members of the Order Diaphanopterodea: Fore and hind wings homonomous or nearly so, the hind wing at most slightly broader than the fore wing, never with an anal lobe; wings held over or along the sides of the abdomen at rest; head with a prominent beak or rostrum, the detailed structure unknown; cerci very long, fully twice the length of the body. The combination of the rostrum, flexed wings, and very long cerci is a unique one and certainly justifies ordinal distinction. 


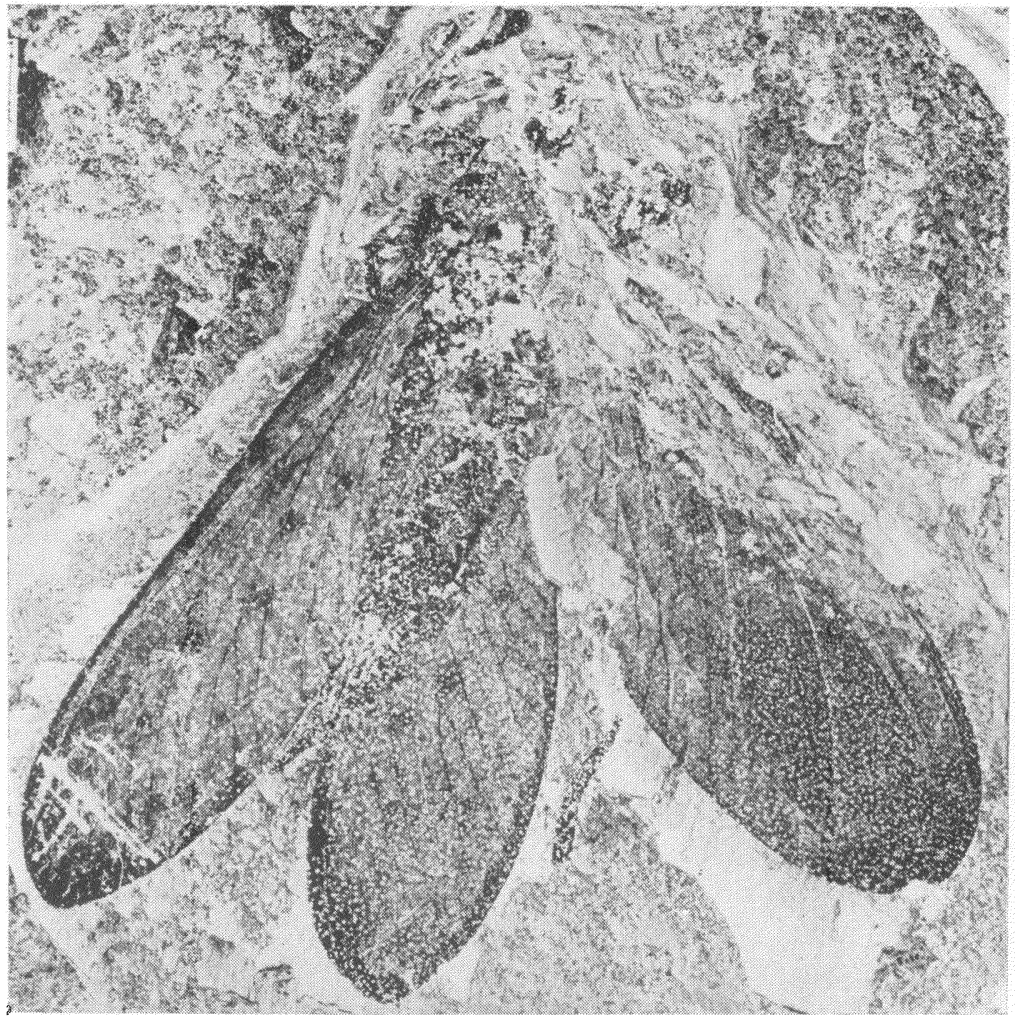

Photograph of Diaphanoptera superba Meunier, type specimen (original, $X 6)$, in Laboratoire de Paleontologie, Paris. The fine white spots visible on wings and body are mineral in nature and also occur on much of the rock surface. 
Within the order several evolutionary trends are recognizable, of which the following four are the most obvious (see plate 30 ) : I. The costal area, starting as moderately broad (Diaphanopteridae, Elmoidae) becomes narrowed distally and eventually very narrow for its entire length (Asthenohymenidae). This change is correlated with the reduction of the subcosta, which clearly terminates on $R_{I}$ in the Diaphanopteridae but in other families tends to end vaguely in the costal space. The cross veins in the costal space also disappear; in the Diaphanopteridae, Elmoidae, and Martynoviidae, these veins form a definite pattern in the proximal part of the wing, the more basal ones slanting towards the wing base, and the immediate ones following slanting towards the apex. Finally, the membrane between $\mathrm{R}_{\mathrm{I}}$ and the costal margin tends to thicken, forming a weak pterostigmal area; this is not visible in the Diaphanopteridae but is in the martynoviids, the prochoropterids, and asthenohymenids. 2. The anastomosis of MA and Rs increases greatly. In the Elmoidae the anastomosis between these veins has not even started, but in the Diaphanopteridae it has clearly begun, and the Martynoviidae show a progressive increase which eventually leads to the near loss of the basal part of MA (Phaneroneura) and the ultimate loss in the Asthenohymenidae. 3 . The stems of $R, M$ and $C u A$ have become coalesced in the more specialized members of the order. In even the most generalized of these families, the base of $\mathrm{CuA}$ has anastomosed with the stem of $\mathrm{M}$, but this compound stem is free from the stem of $\mathrm{R}$ (Diaphanopteridae, Elmoidae); in the Martynoviidae and Asthenohymenidae, these two stems have fused. In the process of this change, a definite pattern of separation of $\mathrm{R}, \mathrm{M}$, and $\mathrm{CuA}$ has taken place, this pattern being already discernible in the Diaphanopteridae: $\mathrm{R}$ diverges anteriorly from $\mathrm{CuA}$, the angle between them being bisected by the stem of $M$. This arrangement finally disappears with the loss of the stem of $M$. It is interesting to note that the basal parts of $\mathrm{Sc}, \mathrm{R}$, and $\mathrm{M}+\mathrm{CuA}$ are arched in all but the most reduced families, this curvature beginning in the Diaphanopteridae and reaching its maximum development in the Martynoviidae and Asthenohymenidae.

In addition to the families mentioned above, several others, previously assigned to the suborder Paramegasecoptera of the Order Megasecoptera, ${ }^{5}$ may also belong to the Diaphanopterodea. These are Parabrodiidae and Raphidiopsidae, from the Upper Carboniferous of the United States; and Kulojidae and Biarmohymenidae from Permian

\footnotetext{
${ }^{5}$ The suborder Paramegasecoptera Carpenter was established (1954) for those Megasecoptera which rested with their wings held back over or along the abdomen.
} 

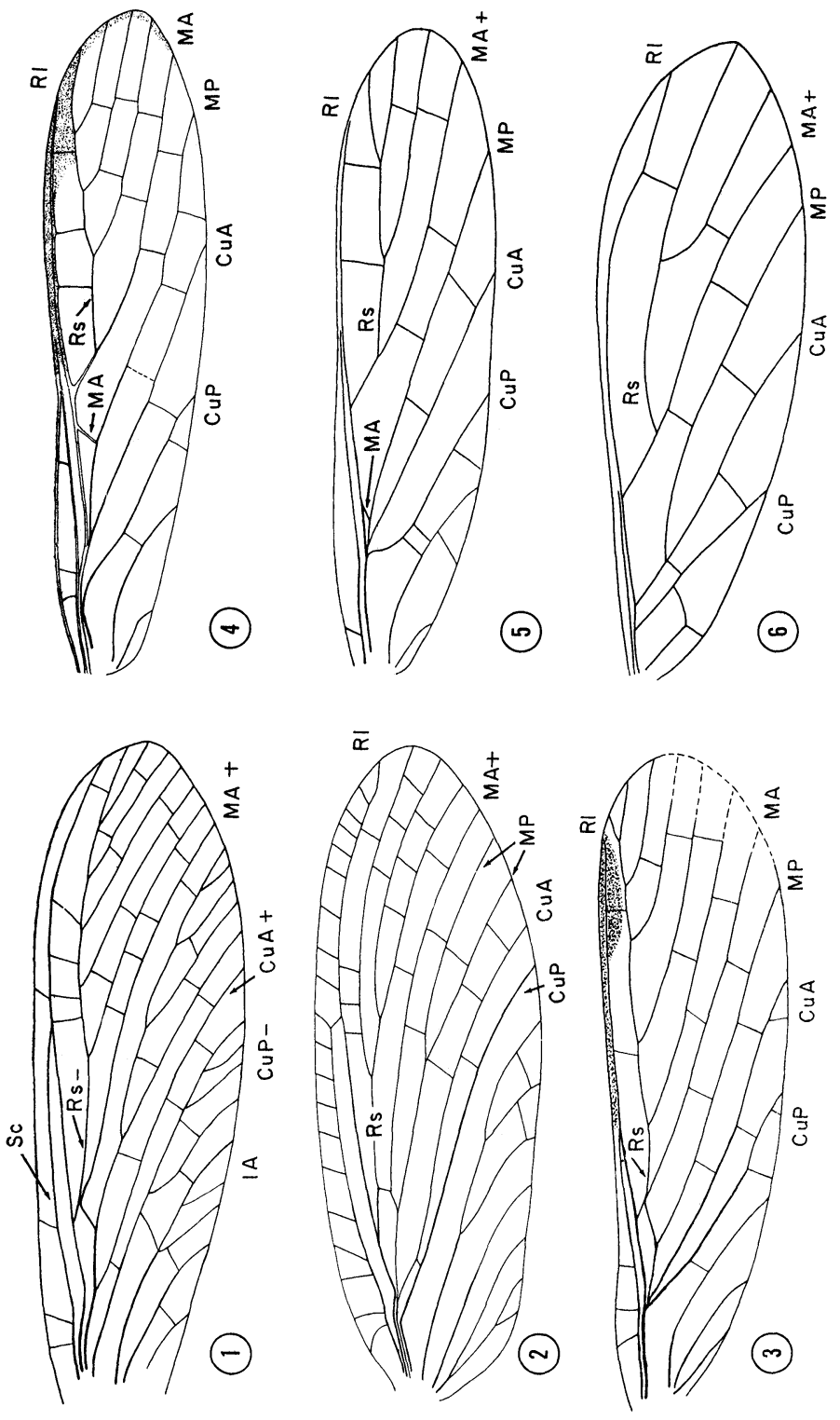

Carpenter - Diaphanopterodea 
beds in the Soviet Union. At present not enough is known about the structure of the members of these families to permit more definite assignment. The Permian family Kaltanelmoidae (Soviet Union), placed in the Diaphanopterodea by Rohdendorf (I962), is so little known and its known structure so peculiar that I doubt that it has affinites with the Diaphanopterodea. The Carboniferous family Sypharopteridae (United States), which is also placed in the Diaphanopterodea by Rohdendorf, definitely belongs to another section of the Insecta. Among its other peculiarities is the complete absence of MA, which occurs as a prominent convex vein in the Diaphanopterodea.

\section{Relationships of the Diaphanopterodea}

In my account of the Megasecoptera of the Wellington formation in Oklahoma (1947), I discussed in some detail the question of the possible relationships of this order, and in particular of those families in the diaphanopterid-asthenohymenid group. Much of what was presented there now pertains to the relationships of the Diaphanopterodea. However, two questions now arise in a different form. First, there is the question of the relationship between the Diaphanopterodea and the Megasecoptera (s.s.). Tillyard ( I936) found it impossible to conceive of the separation of the Asthenohymenidae from the Protohymenoptera on an ordinal level. However, the evidence now strongly indicates that the similarities between these two families are entirely a matter of convergence. The coalescence of MA with $\mathrm{Rs}$ and of the stem of $\mathrm{CuA}$ with $\mathrm{M}$ is certainly in this category: a similar coalescence occurs in several unrelated orders of insects and a great many families within them. What is more important is the distinctive evolutionary trend within the Megasecoptera. The tendency for petiolation of the wings, for extreme and uniform narrowing of the costal space, the loss of costal cross veins, persistence of setae on the costal margin, the straightness of the stems of $\mathrm{Sc}, \mathrm{R}$, and $\mathrm{CuA}+\mathrm{M}$ - all of these represent significant trends in the Megasecoptera not present in

\section{Explanation of Plate 30 \\ ForeWings OF Diaphanopterodea (original drawings)}

1. Diaphanoptera munieri Brongniart, U. Carb., France.

2. Parelmoa revelata Carpenter, L. Perm., Okla.

3. Martynovia insignis Tillyard, L. Perm., Kans.

4. Eumartynov: a raaschi Carpenter, L. Perm., Okla.

5. Phaneroneura martynovae Carpenter, L. Perm., Okla.

6. Asthenohymen apicalis Carpenter, L. Perm., Okla. 
the Diaphanopterodea. These, added to the difference in the resting position of the wings, require, in my opinion, ordinal separation.

Second, there is the more fundamental question of whether the Diaphanopterodea belong to the Neoptera or Palaeoptera, which for the purpose of this discussion are being regarded as monophyletic groups. Unfortunately, we do not know, and probably never will know, whether or not the mechanism of wing flexing in the Diaphanopterodea is the same as that in the Neoptera. One possibility, therefore, is that the Diaphanopterodea are true Neoptera. In this case, because of the long cerci and complete venation (including convex MA), they should be primitive members of the Neoptera - more primitive, in fact, than any other known order in the series (Protorthoptera, Perlaria, etc.). The difficulty with this theory is the presence of a definite rostrum in the Diaphanopterodea. It is hardly conceivable that the mandibulate trophi of the primitive Neoptera (Perlaria, etc.) were derived from such a specialized type. If the Diaphanopterodea were to be regarded as Neoptera, it would be necessary to assume that they were a specialized derivative of even more generalized Neoptera having mandibulate trophi.

A much more appealing view is that the Diaphanopterodea are direct derivatives of the Palaeodictyoptera and that they developed the wing flexing mechanism independently of the true Neoptera. The venation of the Diaphanopteridae could readily be derived from that of the Palaeodictyoptera and what is more important, the rostrum of the Diaphanopterodea is like that of the Palaeodictyoptera. Actually, the rostrum of Stenodictya (Laurentiaux, I952), which I was able to study in Paris in 1963, is remarkably similar to that of the Asthenohymenidae.

Until evidence to the contrary is found, therefore, my view of the Diaphanopterodea is that they are phylogenetically members of the Palaeoptera which have developed a type of wing flexing independently of that of the true Neoptera; and that their closest relatives are the Palaeodictyoptera, from which they were probably directly derived.

\section{References Cited}

Brongniart, Charles

1893 (1894). Recherches pour servir à l'histoire des insectes fossiles des temps primaires. Pp. 1-493.

Carpenter, F. M.

1931. The Lower Permian insects of Kansas. Part 4. The Order Hemiptera and additions to the Palaeodictyoptera and Protohymenoptera. Amer. Journ. Sci. 22 :113-130. 
1939. The Lower Permian insects of Kansas. Part 8. Additional Megasecoptera, Protodonata, Odonata, Homoptera, Psocoptera, Protelytroptera, Plectoptera and Protoperlaria. Proc. Amer. Acad. Arts \& Sci. $73: 29-70$.

1940. Carboniferous insects from the Stanton Formation, Kansas. Amer. Journ. Sci. $38: 636-642$.

1943. The Lower Permian insects of Kansas. Part 9. The Orders Neuroptera, Raphidiodea, Caloneurodea and Protorthoptera (Probnisidae), with additional Protodonata and Megasecoptera. Proc. Amer. Acad. Arts \& Sci. 75:55-84.

1947. Lower Permian insects from Oklahoma. Part 1. Introduction and the Orders Megasecoptera, Protodonata, and Odonata. Proc. Amer. Acad. Arts \& Sci. $76: 25-54$.

Crampton, G. C.

1924. The phylogeny and classification of insects. Pomona Journ. Ent. Zool. 16:33-34.

FORBES, W. T. M.

1924. The occurrence of nygmata in the wings of Insecta Holometabola. Ent. News, $35: 230-232$.

1943. The origin of wings and venational types in insects. Amer. Midl. Natur. 29:381-405.

HANDLIRSCH, A.

1906. Die fossilen Insekten und die Phylogenie der rezenten Formen. Pp. $1-1430$.

1911. New Paleozoic insects from the vicinity of Mazon Creek. Illinois. Amer. Journ. Sci. $31: 297-377$.

1919. Revision der Paläozoischen Insekten. Denkschr. Akad. Wiss. Wien. 96:1-82.

1922. Insecta Palaeozoica (Fossilium Catalogus), (1) 16:1-230.

HAUPT, H.

1940 (1941). Die ältesten geflugelten Insekten und ihre Beziehungen zur Fauna der Jetztzeit. Zeitsch. Naturwissen. Halle. 94:60-121.

Jolivet, $P$.

1955. Recherches sur les organes facettiques des ailes des insectes. Inst. Roy. Sci. Nat. Belg. Bull. $31: 1-23$.

LAMEere, A.

1917. Revision sommaire des insectes fossiles du Stephanien de Commentry. Mus. Nat. d'Hist. Natur. $23: 141-201$.

LaurentiauX, D.

1952. Découverte d'un rostre chez Stenodictya lobata Brgt. (Paléodictyoptère sténodictyide) et le problème des Protohémiptères. Bull. Soc. geol. France (6) $2: 233-247$.

Martynov, A. V.

1923. On two basic types of insect wings and their significance for the general classification of insects. Trudy 1st All Russ. Congress Zool. Anat. Histol. (Petrograd), 1922:88-89. [Russian].

1925. On the facetic organs on the wings of insects. Trav. Soc. Natur. Leningrad $44: 1-23$.

Martynova, O.

1949. Facetic organs on wings of Mecoptera. Bull. Mosc. Obsh. Isp. Priroda, Geol. sec. 24 :93-95. [Russian].

Meunier, F.

1908. Deux nouveaux Mégasécoptères st un nouveau Paléodictyoptère du Stephanien de Commentry. Ann. Soc. Sci. Brux. $32: 2-3$.

Navas, L.

1917. Algunos organos delas alas de los insectos (4). Asoc. Española para el Progreso de las Ciencias, Pp. 57-62. 
ROHDENDORF, B.B., et al.

1962. Osnovy Paleontologii. Akad. Nauk USSR, pp. 1-560. [Russian]. Tillyard, R. J.

1924. Kansas Permian insects. Part 3. The New Order Protohymenoptera. Amer. Journ. Sci. $8: 111-122$.

1926. Kansas Permian insects. Part 16. The Order Plectoptera (contd): the family Doteridae, with a note on the affinities of the Order Protohymenoptera. Amer. Journ. Sci. 32 :435-453.

1937. Kansas Permian insects. Part 17. The Orders Megasecoptera and additions to the Palaeodictyoptera, Odonata, Protoperlaria, Copeognatha and Neuroptera. Amer. Journ. Sci. 33:81-110. 

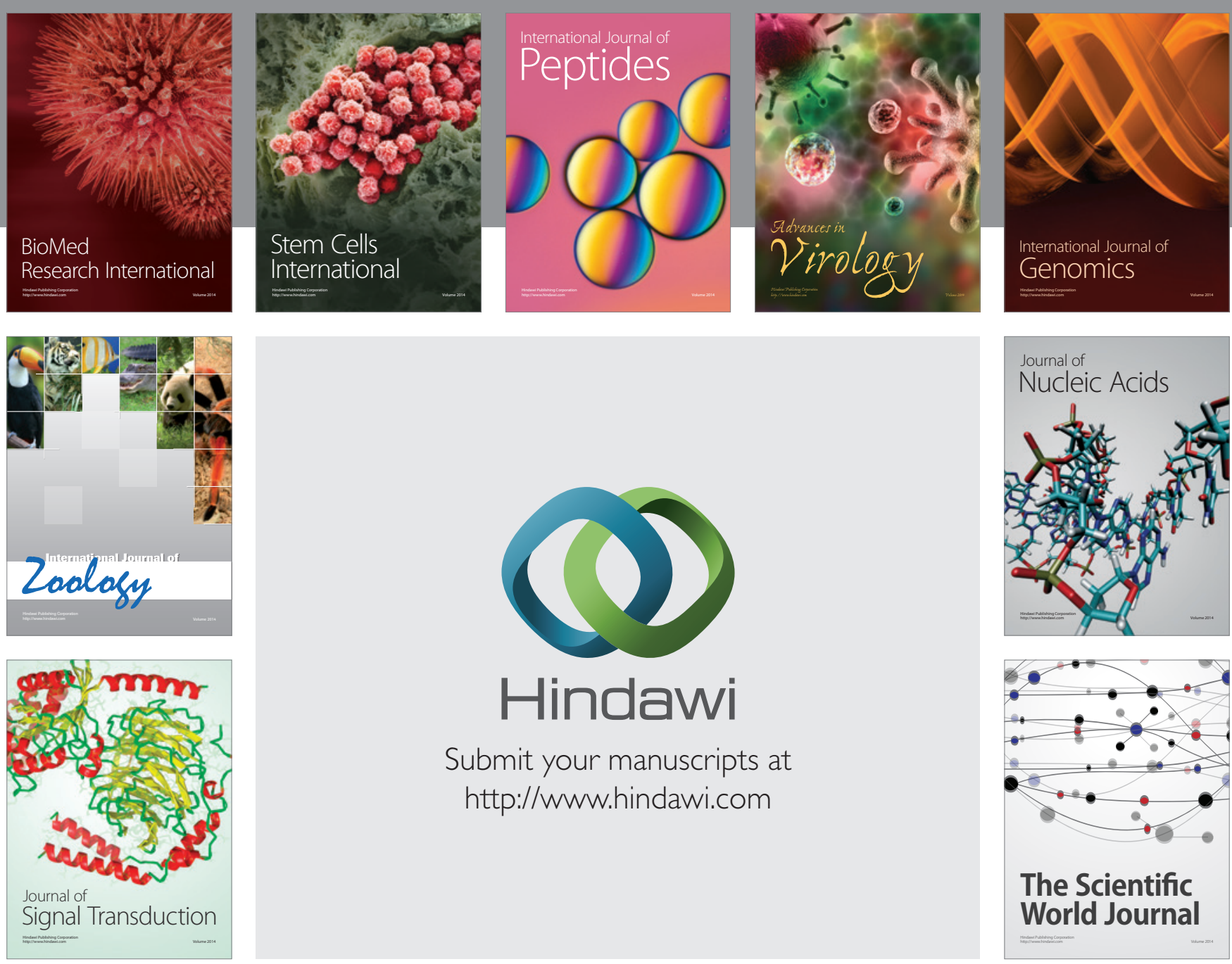

Submit your manuscripts at

http://www.hindawi.com
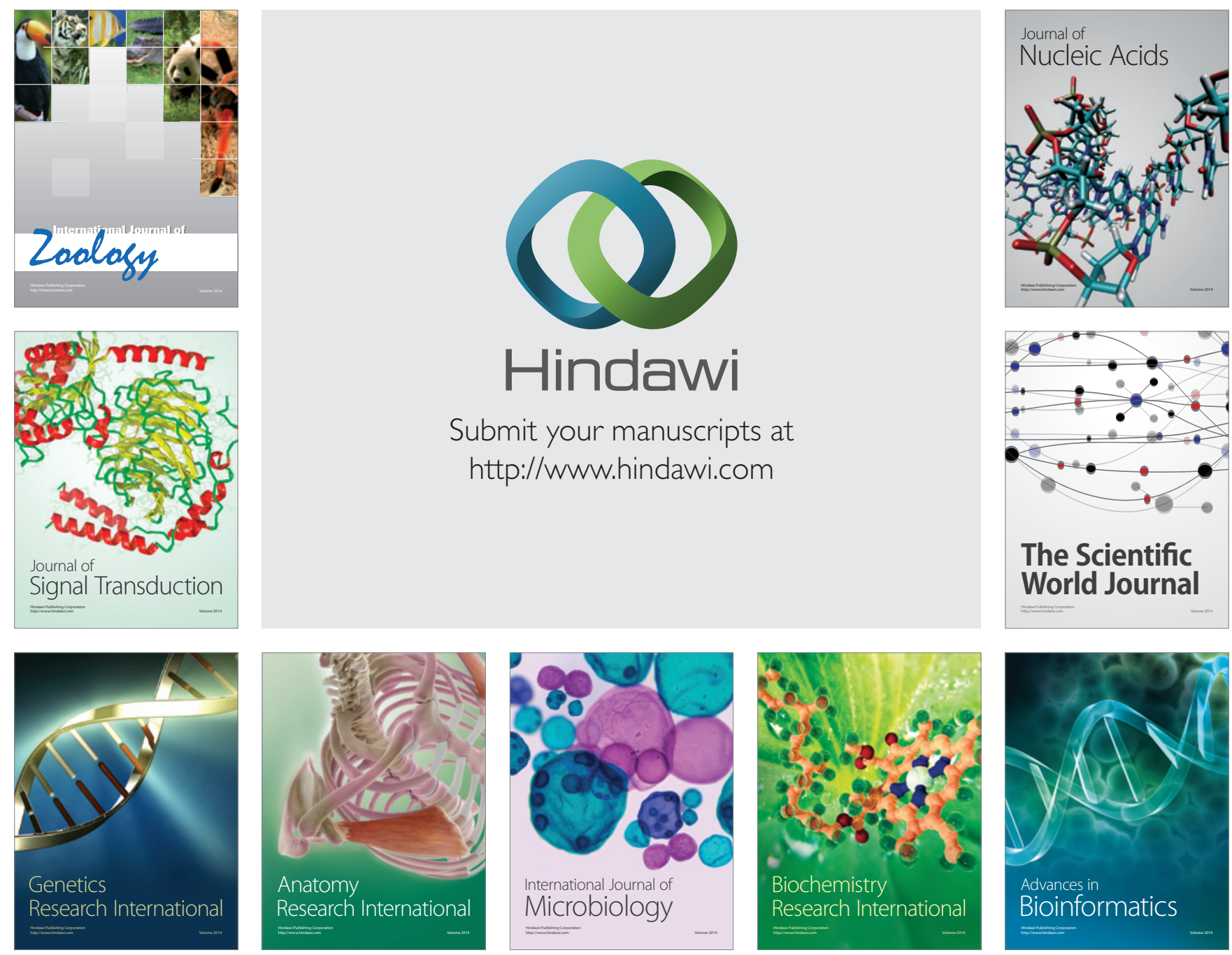

The Scientific World Journal
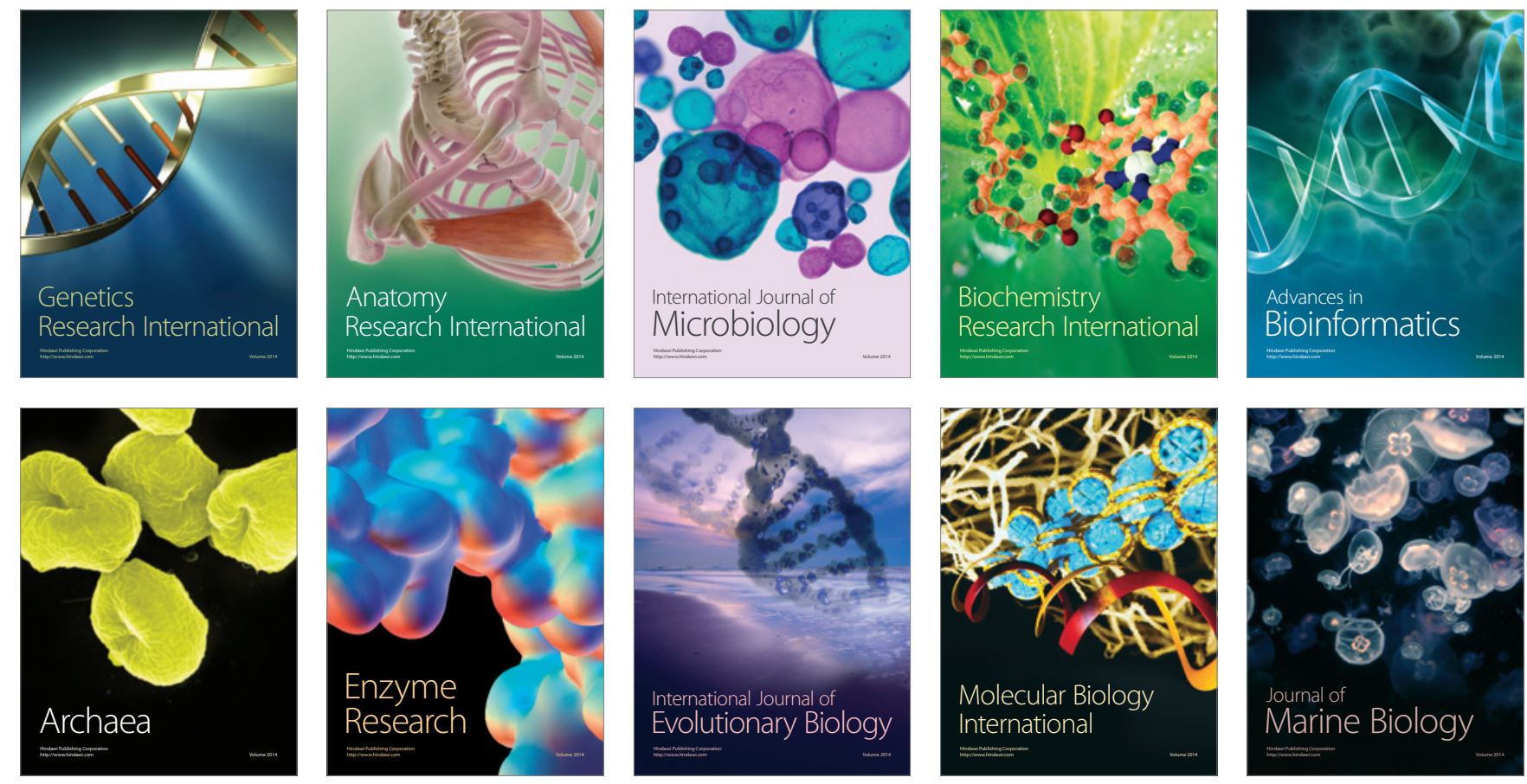